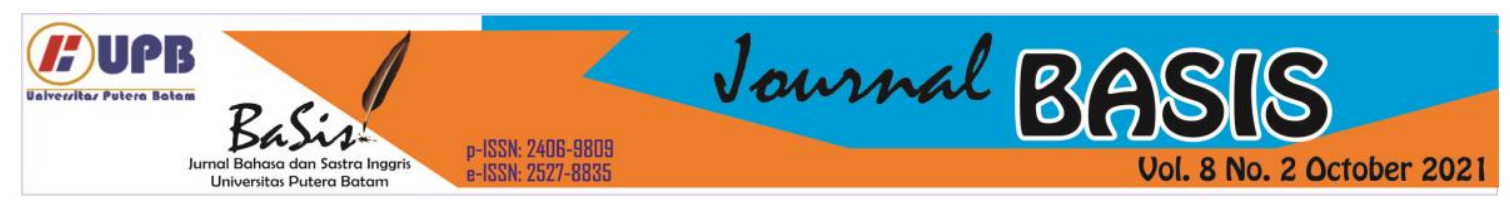

\title{
NON-ENGLISH STUDENTS ‘ATTITUDES TOWARDS LEARNING SPEAKING
}

\author{
Wulida Makhtuna \\ STKIP PGRI Banjarmasin, Banjarmasin, Indonesia \\ wmakhtuna@stkipbjm.ac.id
}

\begin{abstract}
The issue addressed in this research was attitudes of students taking non-English major towards English learning, especially speaking. The study involved 39 students from a compulsory English class at STKIP PGRI Banjarmasin. The data were collected through questionnaires and interviews. The questionnaires were arranged to reveal students' attitudes in three components namely affective, behavioral, and cognitive components. The interviews were conducted to clarify and strengthen the findings from the questionnaires. The results of study showed gaps between affective cognitive components and behavioral one. Most participated students had positive attitudes towards English learning as seen from the affective and behavioral components; however, their behavioral attitudes showed otherwise. Students' behavioral attitudes were still negative towards learning speaking. These positives attitudes were caused by several reasons including their career aspirations and awareness of the importance of English. Furthermore, the negative attitudes were caused by their study priorities and other personal reasons. In conclusion, what they felt and believed about English did not match their efforts to study the language.
\end{abstract}

Keywords: attitudes, students, speaking, English

\section{INTRODUCTION}

Most students in Indonesia have learned English since they were in elementary level of education - or even younger; however, when it comes to proficiency, the results of years of English learning are not satisfactory for many students. This can be caused by several factors including students' attitudes towards English learning. As we know, learning is not only a series of shared activities in the classroom between students and teachers, but it is also a personal experience of each class member. The individual nature of learning makes it understandable that students' attitudes vary from positive to negative towards English.

To define attitudes, Hogg \& Vaughan (2005, p. 150) mention that attitudes refer to what we believe, how we feel, and how we behave in relation to certain 'objects, groups, events or symbols'. Furthermore, according to Stark, Flache, \& Veenstra (2013), attitudes are our tendencies to react in either positive or negative manners towards ideas, objects, people, or situations. Moreover, Mensah, Okyere \& Kuranchie (2013) argue that attitudes portray performance of someone in relation to what they think as well as how they act and behave. From the three definitions above, we can infer that attitudes deal with both mental and behavioral aspects of a person as the response to certain matters.

In the context of language learning, Zulfikar, Dahliana, and Sari (2019) 
mention, "language learning attitude refers to one's tendencies towards their effort in learning languages". From this definition we can conclude that in learning language, attitudes are closely linked to students' efforts in order to achieve mastery of the language being learned. Attitudes of students towards their learning process contribute to their success of learning.

The study on attitudes is greatly influenced by the work of Ostrom (1969). Ostrom is a noble social psychologist known for his ABC model of attitudes. According to him, attitudes have three components namely affective, behavioral, and cognitive components. Affective component of attitudes refers to emotion or feelings of someone towards an object. Behavior component of attitudes refers to how someone behaves towards an object; in other words, behavior component deals with any action taken in relation to a particular object. Cognitive component of attitudes refers to beliefs, opinions, and thoughts someone has in relation to an object. Ostrom's ABC model of attitudes has been implemented in different contexts, including education. In this study, the researcher applied this ABC model of attitudes in the context of English learning.

At STKIP PGRI Banjarmasin, students are required to take two English subjects regardless their majors. These subjects focus more on the development of students' English grammar and speaking ability. At this institution, based on the proficiency test administered by the researcher in the preliminary study, almost all students were in A1 - B1 levels of CEFR. These levels were below proficient users category suggested by CEFR. In terms of speaking ability, the researcher also found that students experienced difficulties in delivering their opinions in English during the class. In short, most of the students were still in the levels of beginner and independent users. By reflecting to this fact, the researcher believed that an investigation of attitudes towards English learning was important to be conducted to determine if students' English proficiency levels were related to their attitudes towards the language.

This research was set to answer the question of "how are students' attitudes towards learning speaking at STKIP PGRI Banjarmasin?" Although in the context of Indonesia there had been many articles written in relation to students' attitudes towards English, this topic remained a new perspective at STKIP PGRI Banjarmasin. In the setting of this institution, the study on students' attitudes towards English learning, especially in terms of speaking skills, was highly needed as none of other researchers had conducted any investigation on this matter before. Therefore, the results of the research were expected to reveal the reasons behind students' low speaking proficiency levels in the perspective of their attitudes towards learning the language.

\section{LITERATURE REVIEW Attitudes towards Learning}

According to Isti and Istikharoh (2019), students' attitudes towards learning are affected by both internal and external factors. The internal factors are associated with individual experiences the students have in relation to studying the language. Furthermore, the external factors include parents, teachers, the learning climate and assignment given, peer groups, and mass media. All these factors shape how students behave and think about the foreign language they are learning. 
Although it is every English teacher's expectation that his/her students show positive attitudes towards the language and the learning process, negative attitudes are commonly shown by students in several aspects. According to Hosseini and Pourmandnia (2013), students with positive attitudes towards the language and the speakers of this language tend to show good performances in the class, and they are able to understand the materials better than those showing negative attitudes. This is also in line with older studies by Karahan (2007), Eshghinejad (2016), Coskun and Tasgin (2018) that emphasize on the impact of positive attitudes towards students' achievement.

Positive attitudes make students involved in the learning process joyfully. They are more motivated in the classroom so that they can follow the class more effectively. On the contrary, students with negative attitudes towards English and its speakers tend to lose their focus of study easily; therefore, their negative attitudes will bring undesirable results for their study.

\section{Previous Studies}

In Indonesia, many researchers have conducted research on students' attitudes towards English. Two research works will be outlined in this study as comparisons. The first one is research work by Zulfikar, Dahliana, and Sari (2019). They investigated English Department students' attitudes towards English learning. The research was conducted qualitatively using interviews as the instrument of data collection. The results of the study showed that English Department students being investigated have positive cognitive, emotional, and behavioral attitudes towards English learning.
The second research work taken as comparison is the study by Iswahyuni and Shefryanto (2018). The objective of their research was to reveal Computer Science students of Brawijaya University's attitudes towards English learning. They investigated three aspects of attitudes namely cognitive, affective, and conative aspects quantitatively using Gardner's Attitude and Motivational Test Battery questionnaire as the instrument of the research. The conclusion of this research is that students showed positive attitudes in all aspects being investigated indicating their interest in learning English.

From the two works outlined above, the significant differences fall on the instruments and respondents of the research. Research by Zulfikar, Dahliana, and Sari (2019) employed only interviews to gain the data, and their focus was English students' attitudes; meanwhile, in this research, data were collected through questionnaires and interviews. Also, the subjects of study in this research were non-English students. Furthermore, in comparison to the study by Iswahyuni and Shefryanto (2018), even both studies collected the data using questionnaire instrument, the questionnaire used in the research of Iswahyuni and Shefryanto (2018) was developed in different manner compared to the one used in this study. Iswahyuni and Shefryanto (2018) arranged the answers to the questions using likert scale while the answers of questions in this research were binary 'agree' and 'disagree' choices. Also, the method of data analysis of this research is mixed-method while Iswahyuni and Shefryanto (2018) analyzed the data quantitatively. 


\section{RESEARCH METHOD}

This study applied mixed-method involving quantitative and qualitative data. According to Creswell (2013, p.32), mixed method enables researchers to achieve a more complete understanding on the phenomena being investigated. The researcher applied mixed-method to ensure the clarity and validity of the findings. In this study, the data were collected through questionnaires and interviews. The questionnaires were analyzed quantitatively. To strengthen the quantitative findings of the data, interviews were conducted and analyzed qualitatively. The interviews were administered semi-structurally so that the researcher as interviewer was able to create impromptu questions as responses to students' answers; by doing so, deeper information could be obtained. Both instruments, questionnaires and interviews, were arranged to reveal students' attitudes in terms of affective, behavioral, and cognitive components.

This study involved 39 students taking ESP 2 class. The students were from two majors: Technology and Information Education and Biology Education. The total students from both majors were more than 40 students; however, not all of them took part in this research. Due to pandemic, the process of data collecting was conducted online. The questionnaires were made using Google Form and distributed via Whatsapp class group. For interviews, 15 students were chosen randomly as respondents.

The results of the questionnaires were analyzed first. The findings then strengthened by the results of interviews. The overall findings were sorted based on the components being analyzed. Each component was described separately. However, the findings of each component were compared to give a better picture on non-English major students' attitude towards learning speaking in an English class.

\section{RESULT AND DISCUSSION}

4.1 Students' Affective Attitudes towards Learning English Speaking

In terms of affective component of attitudes, students showed positive attitudes as reflected in their answers for each question in the questionnaire given to them. Students' affective attitudes towards learning are shown based on their distribution of answers in the table below:

\begin{tabular}{|c|c|c|}
\hline $\begin{array}{c}\text { Affective } \\
\text { Component of } \\
\text { Attitudes } \\
\text { Questions } \\
\end{array}$ & Agree & Disagree \\
\hline $\begin{array}{l}\text { 1. I feel excited } \\
\text { when learning } \\
\text { speaking in } \\
\text { English } \\
\text { classroom. }\end{array}$ & 25 & 14 \\
\hline $\begin{array}{l}\text { 2. I love to hear } \\
\text { someone who } \\
\text { speaks fluent } \\
\text { English. }\end{array}$ & 37 & 2 \\
\hline $\begin{array}{l}\text { 3. I enjoy } \\
\text { learning new } \\
\text { English } \\
\text { vocabularies } \\
\text { from various } \\
\text { sources. }\end{array}$ & 30 & 9 \\
\hline $\begin{array}{l}\text { 4. I want to be } \\
\text { more proficient } \\
\text { in English }\end{array}$ & 39 & 0 \\
\hline $\begin{array}{l}\text { 5. I am sad when } \\
\text { my English is } \\
\text { hard to } \\
\text { understand by } \\
\text { my other } \\
\text { speakers. }\end{array}$ & 30 & 9 \\
\hline
\end{tabular}

Table 1. Summary of Students' Affective Attitudes towards English Learning 
From the answers of five questions arranged to find out students' affective attitudes, none of them showed students' significant disagreement. This means that students' feelings and emotions towards learning speaking were positive. The most significant positivity towards the learning was reflected in students' answers for question number 2 and number 4.37 of 39 participated students (95\%) agreed that they loved it when hearing a fluent speaker of English. Moreover, 100\% of students admitted their eagerness to be more proficient users of English. The two questions were reflections of how the students felt regarding the language.

Furthermore, students' answers on three other questions related to affective attitudes also showed more dominant positive attitudes than negative ones although the percentages were not as high as the two previous questions. 30 of 39 students $(77 \%)$ claimed that they enjoyed learning new English vocabularies, and they would feel disappointed when their English could not be easily understood by others. Again, their answers reflected their positive attitudes of English in terms of affective component. In relation of excitement of learning speaking, even though only 25 of 39 students $(64 \%)$ admitted that they were excited when learning English, the overall number of students who felt excited of learning the language still outnumbered those who felt otherwise $(36 \%)$.

In additions, students' positive affective attitudes towards learning to speak in English were confirmed by the results of interviews. In the interviews, majority of students admitted that they loved it when hearing English is used fluently by someone. They felt someone who speaks English fluently is awesome. Thus, they wanted to be as good as the person. Moreover, they stated that even though they had positive feelings towards English, sometimes their excitement in learning the language could alter due to several reasons including their mood of the day, teachers' delivery, and the time of the class.

\subsection{Students' Behavioral Attitudes towards Learning English Speaking}

Of five questions in behavioral attitudes category, only one question showed students' positive attitudes towards learning English. In the component of behavior, students showed more negative attitudes towards learning as shown in the following table:

\begin{tabular}{|c|c|c|}
\hline $\begin{array}{c}\text { Behavioral } \\
\text { Component of } \\
\text { Attitudes } \\
\text { Questions } \\
\end{array}$ & Agree & Disagree \\
\hline $\begin{array}{l}\text { 1. I practice } \\
\text { English } \\
\text { speaking } \\
\text { regularly not } \\
\text { only in the } \\
\text { classroom but } \\
\text { also outside the } \\
\text { classroom. }\end{array}$ & 12 & 27 \\
\hline $\begin{array}{l}\text { 2. I deliver my } \\
\text { opinions in } \\
\text { English during } \\
\text { the class. }\end{array}$ & 4 & 35 \\
\hline $\begin{array}{l}\text { 3. I take extra } \\
\text { time learning } \\
\text { English (by } \\
\text { joining course, } \\
\text { having study } \\
\text { club, etc.). }\end{array}$ & 14 & 25 \\
\hline $\begin{array}{l}\text { 4. I always do my } \\
\text { English } \\
\text { homework on } \\
\text { time by myself. }\end{array}$ & 20 & 19 \\
\hline $\begin{array}{l}\text { 5. I join English } \\
\text { club. }\end{array}$ & 0 & 39 \\
\hline
\end{tabular}


Behavior component of attitudes in this study is related to actions taken in relation to English learning. It is true that students had positive feelings and emotions towards English as reflected in their answers for questions in affective attitudes category. However, in terms of actions, students still behaved negatively towards English learning. The most significant negative attitudes in behavioral component are shown in students' answers for question number 2 and number 5.35 of 39 students $(90 \%)$ did not deliver their opinions in English during the class. Also, none of the students joined English club to improve their English speaking ability.

The only positive behavioral attitudes towards English learning are shown in students' answers for question number 4 about how they did their English homework. However, the gap between students who did homework on time by themselves with those who did not do the same is not significant. $51 \%$ of students claimed that they did their English homework on time by themselves while $49 \%$ of students claimed the opposite. Therefore, students' positive attitudes in this matter cannot be generalized.

Students' negative behavioral attitudes towards English were also confirmed by the results of interviews. In the interviews, students gave reasons why they did not put extra efforts in learning the language. Most of them admitted that they had already been burdened by so many lessons. They stated that they were tired of learning so that they could not always be diligent in learning every subject. Even though two ESP classes were compulsory for them to take as students of STKIP PGRI Banjarmasin, they were aware of the status of the subjects as minor subjects for their majors. Therefore, they believed that even though they did not put great efforts in learning English, they could still pass the class as long as they attended the class regularly and did any task given by their lecturer.

\subsection{Students' Cognitive Attitudes towards Learning English Speaking}

Of the five questions registered to reveal cognitive attitudes of students towards English learning, only question number 1 showed negative attitudes of students as displayed in the following table:

\begin{tabular}{|c|c|c|}
\hline $\begin{array}{c}\text { Cognitive } \\
\text { Component of } \\
\text { Attitudes } \\
\text { Questions } \\
\end{array}$ & Agree & Disagree \\
\hline $\begin{array}{l}\text { 1. Learning } \\
\text { English } \\
\text { speaking is } \\
\text { easy. }\end{array}$ & 14 & 25 \\
\hline $\begin{array}{l}\text { 2. I believe being } \\
\text { fluent in } \\
\text { speaking } \\
\text { English will } \\
\text { open more } \\
\text { doors for my } \\
\text { career. }\end{array}$ & 39 & 0 \\
\hline $\begin{array}{l}\text { 3. I believe } \\
\text { English is } \\
\text { important to } \\
\text { support my } \\
\text { hobbies/activiti } \\
\text { es. }\end{array}$ & 34 & 5 \\
\hline $\begin{array}{l}\text { 4. I think exposure } \\
\text { of English } \\
\text { outside the } \\
\text { classroom } \\
\text { should be } \\
\text { increased. }\end{array}$ & 39 & 0 \\
\hline $\begin{array}{l}\text { 5. In my opinion, } \\
\text { English should } \\
\text { be taught } \\
\text { intensively } \\
\text { since } \\
\text { elementary }\end{array}$ & 30 & 9 \\
\hline
\end{tabular}


level of study.

Table 3. Summary of Students' Cognitive Attitudes towards English Learning

Students' answers for the question of whether learning English speaking is easy showed their negative thought about the easiness of learning the language. However, other than that question, students showed positive cognitive attitudes towards English learning. The most significant positivity in the segment of beliefs and thoughts regarding English learning are reflected in students' answers for question number 2 and question number 4 . All of them believed that English would be helpful for their career, and they also thought that the exposure of English outside the classroom setting had to be increased.

Although not all students agreed on the statement on the importance of English in supporting their hobbies and activities, $87 \%$ of them believed so. Furthermore, $77 \%$ of students agreed that the teaching of English should be done intensively since beginner level of study. Students' overall answers in cognitive category of attitudes proved their positive beliefs, thoughts, and opinions regarding learning English speaking.

In support to the findings from the questionnaires, in their interviews, students agreed on the statement that English is important. They were fully aware of the opportunity of having better job when they were fluent in speaking English. Some of the students even told the researcher that they wanted to have a career abroad, but they were not sure about their English to support their career aspiration. Moreover, in terms of English exposure, students thought that it would be helpful for them if they were exposed with more English outside the classroom. They told that some of the students could perform better English than them since those students were exposed with more English than them. For example, students studying at Islamic boarding school in Junior and/or Senior High could speak English more confidently as they were used to it at their schools back then. Hence, students believed that more exposure of would help them improve their English.

\subsection{The Gaps between Attitudes' Components}

The gaps between attitudes' components are seen in affective cognitive components and behavioral component. In simple words, students had positive feelings, emotions, beliefs, thoughts, and opinions towards English learning as they were happy about learning the language and believed in its crucial role for their life. However, their actions in regard to English learning were still negative. Students did not give their best in learning the language. The reasons behind negative behavioral attitudes according to them were because of several factors include their hesitance of using the language, their learning priority, and their fear of being bullied when making mistakes regarding the language.

Based on the interviews, the researcher concluded that hesitance of using English occurred because students did not feel confident about their English. The fear of being bullied or labeled by their peers made the situation worse. They chose to be more passive than pushing themselves to be more engaged in the learning process as they felt that by doing so they could escape from what they were afraid of. In addition, as English is not their major, many students believed that they should prioritize their time to study other subjects than English. Therefore, they did not feel any obligation to join the course or any English club to improve 
their English. Also, the students claimed that they were already tired of learning other subjects in their majors. They knew English is important but their mastery of subjects linear to their majors is more important for them.

The gaps between how students behaved and what they felt and believed make it explainable why for most of the students, even though they have learned English for years, their English is not in fluent level yet. Ideally, of course English learners must have positive attitudes towards the learning in all aspects. However, the fact shows that students are overwhelmed with so many lessons to master so that sometimes they have to prioritize what to study intensively. Unfortunately, English is not always priority especially for students whose majors are not English.

\section{CONCLUSIONS}

The findings of this study suggested that students' attitudes towards learning speaking were both positive and negative. The positive attitudes were shown in affective and cognitive components of attitudes. Affectively, the students felt the joy of learning to speak English. They were also eager to be more fluent users of English. Cognitively, the students were aware of the important of English for their future. However, students' behaviors in relation to English learning were still negative. They neither put extra efforts in learning the language in classroom nor outside the classroom. This attitude gap caused students yet to achieve the desired result of their English learning.

\section{REFERENCES}

Coskun, G. \& Taskin, A. 2018. An Investigation of Anxiety and Attitudes of University Students towards English Courses.
Journal of Language and Linguistic Studies, 14(2), 135153.

Creswell, J. W. (2013). Qualitative Inquiry \& Research Design: Choosing among Five Approaches (3rd ed.). Thousand Oaks, CA: SAGE.

Eshghinejad, S. 2016. EFL students' attitudes toward learning English language: The case study of Kashan University students, 113. Retrieved from https://eric.ed.gov/?id=EJ113827 $\underline{7}$

Hogg, M., \& Vaughan, G. (2005). Social Psychology (4th edition). London: Prentice-Hall.

Hosseini,S., \& Pourmandnia, D. (2013). Language Learners' Attitude and Belief: Brief Review of the Related Review Literature and Frameworks. International Journal on New Trends in Education and Their Implications, 4 (4), 63-74.

Isti, M. \& Istikharoh, L. (2019). EFL Students' Attitude toward Learning English. JSSH (Jurnal Sains Sosial dan Humaniora), 3 (2), 95-105.

Iswahyuni \& Shefryanto, F.J. (2018). Computer Science Students' Attitudes towards English Language Learning. EDUCAFL: Journal on Education of English as Foreign Language, 1 (2), 1-4.

Karahan, F. 2007. Language Attitudes of Turkish Students towards the English Language and its Use in Turkish Context. Journal of Arts and Sciences Say, 73-87.

Mensah, J., Okyere, M., \& Kuranchie, A. (2013). Students Attitude towards Mathematics and Performances: Does the Teacher Attitude Matter?. Journal of 
education and practice, 3, 132139.

Ostrom, T. M. (1969). The Relationship between the Affective, Behavioral, and Cognitive Components of Attitude. Journal of Experimental Social Psychology, 5(1), 12-30.

Stark, T. H., Flache, A., \& Veenstra, R. (2013). Generalization of Positive and Negative Attitudes toward Individuals to Outgroup Attitudes. Personality and Social Psychology Bulletin, 39 (5), 608622.

Zulfikar, T., Dahliana S., \& Sari, R. A. (2019). An Exploration of English Students' Attitude towards English Learning. English Language Teaching Educational Journal, 2 (1), 1-12. 
